Boise State University

ScholarWorks

$10-3-2012$

Institutional Repository Management Models that Support Faculty Research Dissemination

Michelle Armstrong

Boise State University 


\section{INSTITUTIONAL REPOSITORY MANAGEMENT MODELS THAT SUPPORT FACULTY RESEARCH DISSEMINATION}

Michelle Armstrong

Albertsons Library

Boise State University

In his remarks to ARL Dr. Shulenberger discussed a survey he had conducted of Provosts, asking if universities had strategies for disseminating the scholarship they produced. Only a handful provided any kind of affirmative response. The bottom line is the dissemination of scholarship is left up to the individual professor. And in academia, the only really acceptable method of dissemination is through peer-reviewed journals. This system of dissemination is virtually unchangeable since is supported by the tenure process. Since this is pretty much the standard for universities across America, there has been little impetus for faculty or even universities for that matter, to investigate or change how the scholarship produced in their institutions is disseminated.

Dr. Shulenburger's comments, along with the ideas set forth in the "The University's Role in the Dissemination of Research and Scholarship" document, question that status quo and in fact asserted that universities have responsibility to facilitate the dissemination of the research and knowledge produced at their institutions.

Trends that are driving a more organized approach to research dissemination:

- growth of IRs on university campuses - we are starting to have the infrastructure to support dissemination

- Exploding journal prices - libraries and other advocates are looking for alternatives to traditional journal publishing

- Developing awareness of the value of datasets and exploration on how to provide access to these assets

- Federal policies, such as those required by NSF regarding data management, initiate centralized efforts in universities to ensure compliance with these requirements.

\section{Framing the Repository as a Service}

At times there can be a disconnect between librarian needs and faculty needs.

Focusing on the benefit to the researcher, author, and university at large:

- Create services that cater to faculty needs

- Download statistics for tenure

○ Making them and their departments look good 
- Discoverability of faculty scholarship - optimizing for search engines

- Using a personal touch

- Language and marketing

- Conscientious IR Policies

Challenge yourself to look objectively at the work you do. Are you truly offering a service that benefits your patrons?

\section{Mediated Deposit}

Basically this is the "do it for them" approach. At Boise State, we complete many task on the behalf of faculty authors: identify eligible publications, clearing copyright, soliciting author permission, and uploading their works.

The key issue for this model is that the library has to have the necessary infrastructure in place to support this kind of service.

Try reading Dorothea Salo's "Innkeeper at the Roach Motel” article for a commentary on problematic management models used by institutional repositories.

\section{Mass Customization}

The concept was developed in the early 1990's primarily by Joseph Pine to describe a shift in business processes away from mass production, that was characterized by the focus on the process of production and standardization and instead towards mass customization, that utilizes variety and flexibility, often driven by newer technologies and a modular approach, to deliver a unique product for an individual.

By applying the concept of mass customization, we have had terrific success, particularly with the creation of SelectedWorks sites for faculty authors. Currently we have created and maintain 367 sites, which is approximately $70 \%$ of all Boise State faculty.

Use technology to support mass customized services.

Not everything has to be customized however. Figure out where you will get the greatest impact from your efforts.

\section{Library-Based Publishing}

In Fall 2007, a survey was conducted of ARL member libraries regarding their publishing services. The survey defined library-based publishing as "the organized production and dissemination of scholarly works in any format as a service provided by a library" ("Campus Publishing," 2007). 
Simply housing or digitizing documents was not considered publishing in that survey. Many institutional repositories do that, but I wouldn't consider that to be original publishing in the true sense.

The follow-up report noted several common services provided by libraries including: hosting, digitization, copyright advising, and editing.

Although there are many different components involved in publishing, one of the most common activities libraries are engaging in is the hosting of journals. Two platforms frequently used are the Open Journal Systems, an open source publishing tool and the electronic journal feature included in Digital Commons. Both systems allow librarians to work with faculty to solicit submissions, manage peer-review processes, and provide indexing and other discovery tools

\section{References}

Association of American Universities, Association of Research Libraries, Coalition for Networked Information, National Association of State Universities and Land Grant Colleges. (2009). The University's Role in the Dissemination of Research and Scholarship-A Call to Action. Research Library Issues: A Bimonthly Report from ARL, CNI, and SPARC, no. 262, 1-6. Retrieved from http://www.arl.org/resources/pubs/rli/

Association of Research Libraries. (2010). Campus Publishing and Library Publishing Services. Retrieved from http://www.arl.org/bm doc/cplp_survey_2007.pdf

Gilmore, J. H., \& Pine, B. J. (2000). Markets of one: Creating customer-unique value through mass customization. Boston, Mass: Harvard Business School Press.

Hahn, K. L. (2008). Research library publishing services: New Options for university publishing. Retrieved from Association of Research Libraries website: http://www.arl.org/bm doc/research-librarypublishing-services.pdf

Pine, B. J. (1993). Mass customization: The new frontier in business competition. Boston, Mass: Harvard Business School Press.

Salo, D. (2008). Innkeeper at the roach motel. Library Trends, 57(2), 98-123.

Shulenburger, D. (2007). University research publishing or distribution strategies?. Remarks presented at the 151st ARL Membership Meeting, Washington DC, October 11, 2007. Retrieved from http://www.arl.org/bm $d o c / m m-f 07-s h u l e n b u r g e r . p d f$ 